\title{
RARE CASE OF PERSISTENT HYPOXEMIA
}

Anbu Maran Parivakkam Mani', Shanmugapriya K2, Thangaswamy Dhansekar ${ }^{3}$, Gangadharan Veluswamy4, Sathish Kumar Mani ${ }^{5}$

${ }_{1}^{1}$ Senior Resident, Department of Respiratory Medicine, Saveetha Medical College and Hospital, Kanchipuram, Tamilnadu, India. ${ }^{2}$ Senior Resident, Department of Respiratory Medicine, Sri Ramachandra Medical College and Research Inistitute, SRIHER, Tamilnadu, India.

${ }^{3}$ Professor, Department of Respiratory Medicine, Sri Ramachandra Medical College and Research Inistitute, SRIHER, Tamilnadu, India. ${ }^{4}$ Professor, Department of Respiratory Medicine, Saveetha Medical College and Hospital, Kanchipuram, Tamilnadu, India.

${ }^{5}$ Assistant Professor, Department of Respiratory Medicine, Saveetha Medical College and Hospital, Kanchipuram, Tamilnadu, India.

HOW TO CITE THIS ARTICLE: Mani AMP, Shanmugapriya K, Dhansekar T, et al. Rare case of persistent hypoxemia. J. Evolution Med. Dent. Sci. 2018;7(52):5573-5575, DOI: 10.14260/jemds/2018/1233

\section{PRESENTATION OF THE CASE}

A 40 year old male patient, farmer by occupation, presented with complaints of abdominal pain on and off for the past 20 days, increased for the past 2 days over the left lumbar region, colicky pain, non-radiating, associated with burning micturition, no complaints of nausea, vomiting, constipation, loose stools, fever, loss of weight, loss of appetite, shortness of breath, cough with expectoration or chest pain. No co-morbidities, no history of smoking or alcoholism. ${ }^{1}$

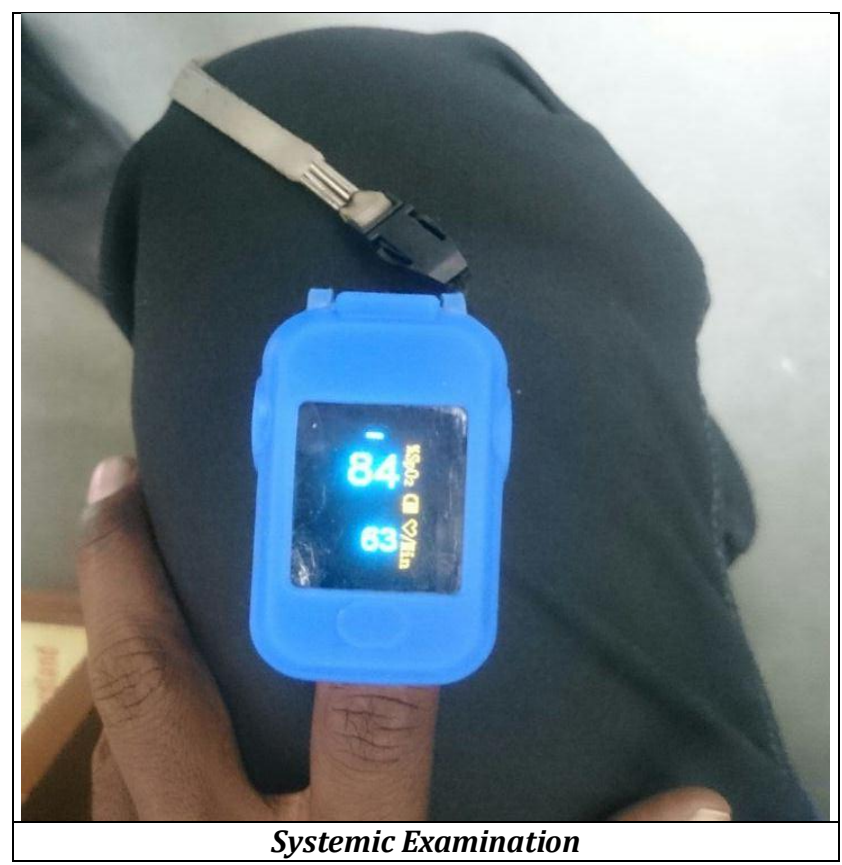

Rs- bilateral normal vesicular breath sounds, no added sounds, CVS- S1S2 heard, no murmurs, per abdomen -mild lumbar tenderness present over the left side, CNS- no focal neurological deficit.

'Financial or Other Competing Interest': None.

Submission 30-11-2018, Peer Review 13-12-2018,

Acceptance 15-12-2018, Published 24-12-2018.

Corresponding Author:

Anbu Maran Parivakkam Mani,

No. 2, Navalar Street, Avadi Road,

Karaiyanchavadi-Dist. Poonamallee,

Chennai-600056,

Tamilnadu, India

E-mail: anbumaran.mbbs@gmail.com

DOI: $10.14260 /$ jemds/2018/1233

\section{(c) (i) $(9)$}

\section{CLINICAL DIAGNOSIS}

On examination- well-built and nourished, no pallor, icterus, clubbing, cyanosis, lymphadenopathy or pedal oedema. Vitals- Temperature-afebrile, pulse rate- $63 / \mathrm{min}$, respiratory rate- $20 / \mathrm{min}$, blood pressure- $120 / 80 \mathrm{mmHg}, \mathrm{SPO}_{2}-84 \%$ at room air.

\section{DIFFERENTIAL DIAGNOSIS}

1. Cyanotic congenital heart disease (Right to Left Shunt).

2. Pulmonary thromboembolism.

3. Methaemoglobinaemia.

4. Sulfhaemoglobinaemia. ${ }^{5}$

\section{PATHOLOGICAL DISCUSSION}

Hb- $14.6 \mathrm{gm} / \mathrm{dL}$, total count- 5500 cells/cu.mm, RFT, LFTwith in normal limits, peripheral smear-normal study, Chest X-ray -normal,

$\mathrm{ABG}$ at room air-PH-7.40, $\mathrm{PCO}_{2}-47.6 \mathrm{mmHg}, \mathrm{PO}_{2}-67.1$ $\mathrm{mmHg}, \mathrm{HCO}_{3}-2$ 28.9. 2D-ECHO-Normal chamber dimensions, PAP- $20 \mathrm{mmHg}$, EF-64\%,

PFT and diffusion studies were found to be normal. Holter monitoring showed no significant abnormalities. 6 minute walk test showed no desaturation from baseline of $84 \%$

CT -KUB showed left distal ureteric calculi causing mild hydroureteronephrosis. Patient was planned to undergo lithotripsy and left DJ stenting.

Pulmonologist and cardiologist opinion was sought in view of persistent hypoxemia.

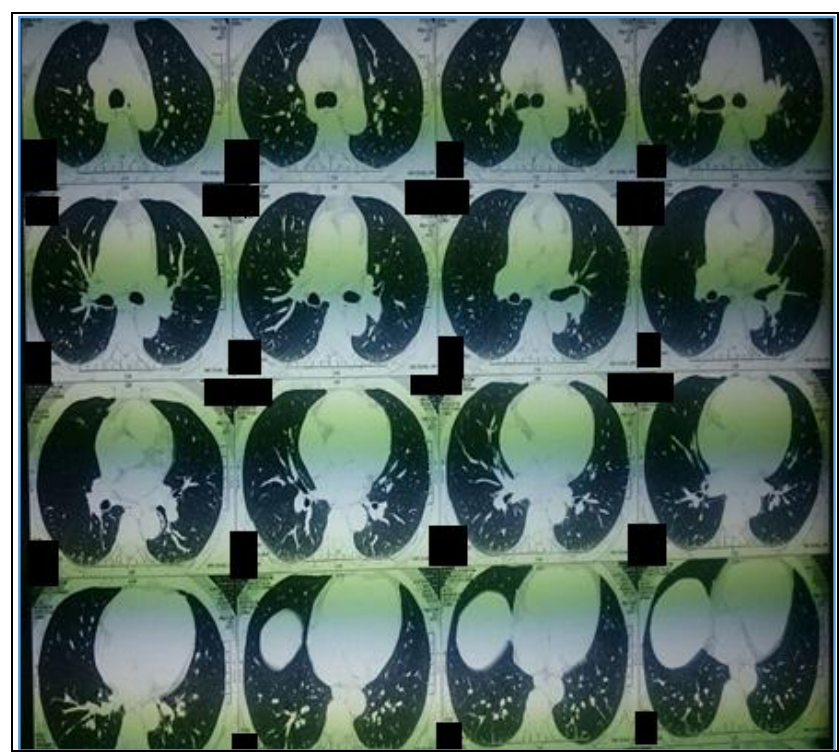



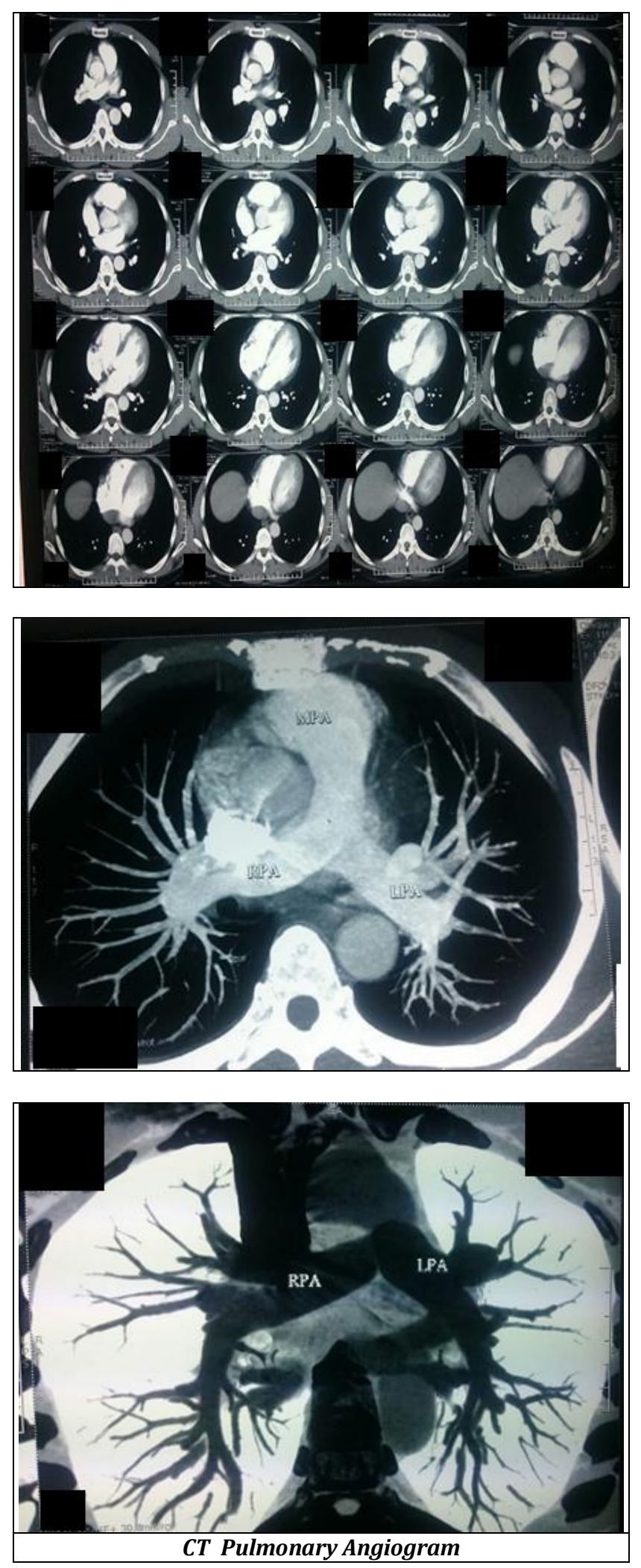

\section{CT Pulmonary Angiogram}

Cardiac and respiratory evaluations were found to be normal. On persistent history, patient denies history of exertional dyspnoea, on retrospective history-patient gave history of exposure to pesticides (Bifenthrin, cartap hydrochloride, kasugamycin, cypermethrin) used in agricultural field for the past 7 years, no family history of cyanosis, patient suspected to have haemoglobinopathies and evaluated further. ${ }^{2}$

\section{Chromatogram}

Normal study, carboxyhaemoglobin-7\% (Reference value$12 \%$ ), methaemoglobin-26.4 (Ref. value- $<1.5$ ), reticulocyte count- 2.1.

Patient was diagnosed to have methemoglobinemia patient was planned for methylene blue therapy, for which G6PD deficiency was ruled out.

G6PD -11.3 U/gHb (ref-6.4-18.8).

Direct and indirect coombs test was negative. ${ }^{3}$

\section{DISCUSSION OF MANAGEMENT}

Methaemoglobinaemia is a condition characterised by increased quantities of haemoglobin in which the iron of haeme is oxidised to Ferric form. ${ }^{6}$

Methaemoglobin has got decreased affinity for oxygen and so decreased availability of oxygen to the tissues.

Types-

Congenital

Due to deficiency of enzyme nicotinamide adenine dinucleotide NADH cytochrome b5 reductase, which helps in conversion of methaemoglobin to functional haemoglobin.

\section{Congenital type is again classified as -}

1. Erythrocytic - here the soluble form of enzyme is deficient only in the erythrocytes.

2. Generalised- where the membrane bound form of enzyme is deficient in all tissues causing severe developmental abnormalities.

\section{Acquired}

Due to exposure to drugs and chemicals commonly used in cardiac and anaesthetic procedures, which oxidizes haemoglobin to form methaemoglobin. ${ }^{7}$

Drugs causing methaemoglobinaemia are acetanilide, alloxan, aniline, arsine, benzene derivatives, bivalent copper, bismuth, bupivacaine, chorates, chloroquine, chromates, dapsone, dimethyl sulfoxide, dinitrophenol, exhaust fumes, ferricyanide, flutamide, hydroxylamine, lidocaine, metoclopramide, naphthalene, nitrates, nitrofuran, nitroglycerin, sodium nitroprusside, paraquet, phenacetin, phenol, phenytoin, rifampin, sulphasalazine and sulphonamides

Cardiologist opinion was sought in view of methylene blue infusion.

Patient was given methylene blue infusion of $1 \mathrm{mg} / \mathrm{kg}$ body weight over 20 mins, SPO2 improved to $99 \%$ at room air.

During and post procedure vitals monitoring was found to be normal.

\section{Follow-Up}

Patient was reviewed after 1 month, and repeat saturation was found to be $94 \%$ at room air. repeat methaemoglobin levels were found to be $16.2 \%{ }^{4}$

Patient was planned for one other methylene blue infusion on follow up.

Severe acute methaemoglobinaemia requires immediate therapy, whereas chronic asymptomatic patients will not 
require active therapy and in case of hereditary methaemoglobinaemia there is no pharmacological treatment available.
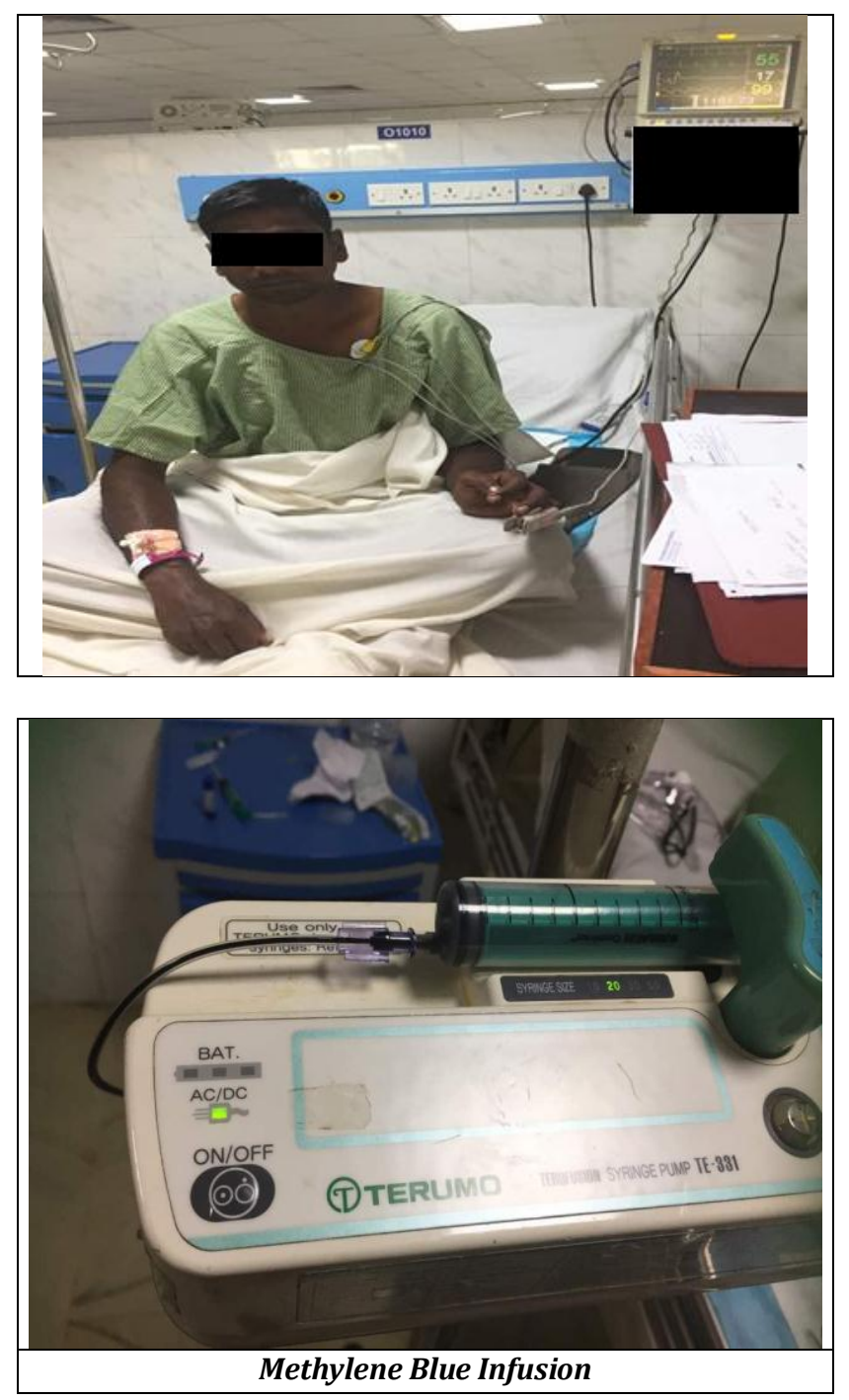

Initial management includes supplemental oxygen, identification of aetiology and avoiding exposure to the chemical and drugs. ${ }^{8}$
Methylene blue ( $1 \mathrm{mg} / \mathrm{kg} /$ body weight) - contraindicated in G6PD deficiency.

Others include exchange transfusion and hyperbaric oxygen therapy, where methylene blue is contraindicated or ineffective. Ascorbic acid, riboflavin, $\mathrm{N}$-acetyl-cysteine are the other supportive drugs given.

\section{FINAL DIAGNOSIS}

Methaemoglobinaemia.

\section{REFERENCES}

[1] Manabe J, Arya $R$, Sumimoto $H$, et al. Two novel mutations in the reduced nicotinamide adenine dinucleotide (NADH)-cytochrome $b_{5}$ reductase gene of a patient with generalized type, hereditary methemoglobinemia. Blood 1996;88(8):3208-15.

[2] Gibson QH. The reduction of methemoglobin in red blood cells and studies on the cause of idiopathic methemoglobinemia. Biochem J 1948;42(1):13-23.

[3] Yawata Y, Ding L, Tanishima K, et al. New variant of cytochrome $b_{5}$ reductase deficiency (b5Rkurashiki) in red cells, platelets, lymphocytes and cultured fibroblasts with congenital methemoglobinemia, mental and neurological retardation and skeletal anomalies. Am J Hematol 1992;40(4):299-305.

[4] Worster-Drought C, White JC, Sargent F. Familial, idiopathic methaemoglobinaemia associated with mental deficiency and neurological abnormalities. $\mathrm{Br}$ Med J 1953;2(4828):114-8.

[5] Askew GL, Finelli L, Genese CA, et al. Boilerbaisse: an outbreak of methemoglobinemia in New Jersey in 1992. Pediatrics 1994;94(3):381-4.

[6] Ohashi K, Yukioka H, Hayashi M, et al. Elevated methemoglobin in patients with sepsis. Acta Anaesthesiol Scand 1998;42(6):713-6.

[7] Pollack ES, Pollack CV Jr. Incidence of subclinical methemoglobinemia in infants with diarrhea. Ann Emerg Med 1994;24(4):652-6.

[8] Hjelt K, Lund JT, Scherling $B$, et al. Methaemoglobinaemia among neonates in a neonatal intensive care unit. Acta Paediatr 1995;84(4):365-370. 